\title{
Improvement of innate immune responses and defense activity in tiger shrimp (Penaeus monodon Fab.) by intramuscular administration of the outer membrane protein Vibrio alginolyticus
}

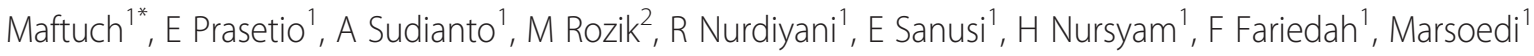
and Murachman ${ }^{1}$

\begin{abstract}
The Outer Membrane Protein (OMP) of Vibrio alginolyticus cell wall was administered intramuscularly (IM) to the tiger shrimp (Penaeus monodon Fab.) at 10, 20,30 $\mathrm{\mu g} / \mathrm{kg}$ bw. After 14 days infection, the tiger shrimps were challenged with $10^{7}$ bacterial density of Vibrio harveyi for 24 hours. The total haemocyte count (THC), differential haemocyte count (DHC) and amount of total protein plasma (TPP), superoxide dismutase and protease enzyme activity were monitored. The results showed that intramuscular administration of OMP enhanced an immunomodulatory effect and protection against $V$. harveyi. The beneficial effect of OMP on the tiger shrimp is dose-dependent and OMP-20 $\mu \mathrm{g} / \mathrm{kg}$ bw is an optimal dose after two times of boosters for 14 days against $V$. harveyi infection.
\end{abstract}

Keywords: Outer membrane protein; Immunomodulation; Tiger shrimp; Vibrio harveyi

\section{Introduction}

Tiger shrimp (Penaeus monodon Fabricus) are one of the most important aquaculture products in several countries, especially in South-East Asia. But in Indonesia, tiger shrimp have almost entirely disappeared because of diseases. Disease problems in aquaculture are caused by environmental problems such as poor water conditions, leading to stress and disease outbreaks (Sadovy, 2000). The big disease outbreaks in tiger shrimp aquaculture are caused by viruses and bacteria e.g., Vibrio spp. Therefore, control of diseases is an important task for the further development of tiger shrimp culture.

There are many techniques widely used to control the diseases, such as using antibiotics and chemotherapy. However, experience demonstrates that there are several problems associated with the use of antibiotics and chemotherapy in clinical treatment of shrimp diseases. Such as, potential environmental hazards, the spread of antibiotic-resistant bacteria and associated stress (Jin et al.

\footnotetext{
* Correspondence: maftuch@ub.ac.id

'Fisheries and Marine Science Faculty, Brawijaya University, Malang, East Java, Indonesia

Full list of author information is available at the end of the article
}

2008). Thus, researchers have focused on finding alternative methods of disease control such as the application of vaccines and immunostimulants of microbial origin (Sakai, 1999). The OMP is an effective microbial origin immunostimulant and has been successfully used to strengthen the non-specific defense systems of shrimp and also non-specific and specific defense systems of fish (Maftuch, 2006). The OMP was isolated from the Vibrio alginolyticus cell wall.

Many reports showed that OMP contain LPS, betaglucan and proteins that can enhance macrophage phagocytic activity, which is part of the non-specific defense system (Jin et al. 2008). However, there are a few reports about the application of OMP in Shrimp. The purpose of the study was to explore the effect of OMP on the immune response in tiger shrimp, as well as on resistance against Vibrio harveyi.

\section{Materials and methods}

\section{Preparations of outer membrane (OMP) from}

\section{V. alginolyticus}

V. alginolyticus strains were isolated from pathogenic shrimp (Penaeus monodon Fab.) that cultured in marine 
ponds at the Research Centre of Brackish Water, East Java Province, Indonesia. The isolate was cultured on thiosulfate-citrate-bile salt-sucrose (TCBS) agar plates. Therefore the $V$. alginolyticus was grown in $1000 \mathrm{ml}$ Brain Heart Infusion Broth (BHIB) at $30^{\circ} \mathrm{C}$ for 24 hours, and then were separated into 100 bottles containing Thiaproline Carbonate Glutamate (TCG) medium at $30^{\circ} \mathrm{C}$, for 48 hours to enrich growth pili of $V$. alginolyticus. The medium contains $0.02 \%$ Thioproline, $0.3 \% \mathrm{NaHCO}, \quad 0.1 \%$ monosodium l-glutamate, $1 \%$ bactotryptone, $0.2 \%$ yeast extract, $0.5 \% \mathrm{NaCl}, 2 \%$ bacto agar and $1 \mathrm{mM}$ Beta-amino ethyl ether $\mathrm{N}, \mathrm{N}, \mathrm{N}$, " $\mathrm{n}$ "-tetra acetic acid (EGTA).

OMP was isolated from both pili (growth medium) and cell membrane (cell pellet), following (Garavito and Rosenbusch 1986). The pili were isolated using micro centrifugation $\left(3,500 \mathrm{~g}, 15 \mathrm{~min}, 4^{\circ} \mathrm{C}\right)$ six times. The Pili's content was put in the solution. The cell pellet (1 gram) was resuspended in $15 \mathrm{ml}$ of lysis buffer. After incubation for 1 min with gentle shaking and centrifugation at $12,000 \mathrm{~g}$ and $4^{\circ} \mathrm{C}$ for $30 \mathrm{~min}$, the solution containing the membrane fraction was dialyzed for 24 hours by $\mathrm{dH}_{2} \mathrm{O}$ and following with Phosphate Buffer Saline (PBS) pH 7.4 for 24 hours. The determination of protein concentration was estimated using the BCA assay kit (Pierce, Rockford, IL, USA) according to the manufacturer's instructions. A protein sample $(12.5 \mu \mathrm{l})$ was mixed with $100 \mu \mathrm{l}$ of the BCA working reagent. After the reaction mixture was incubated at $37^{\circ} \mathrm{C}$ for $30 \mathrm{~min}$, absorbance at $540 \mathrm{~nm}$ was measured with a microplate reader spectrophotometer (Labsystem, Finland). BSA at various concentrations, ranging from 0.025 to $1.0 \mathrm{mg} / \mathrm{ml}$, was used to construct a standard calibration curve and to determine protein concentrations of the samples.

\section{Preparation of $V$. harveyi}

$V$. harveyi strain was isolated from pathogenic shrimp (P. monodon Fab.) from marine ponds at the Research Centre of Brackish Water, East Java Province, Indonesia. The isolate was cultured on thiosulfate-citrate-bile saltsucrose (TCBS) agar plates, and then grown in $1000 \mathrm{ml}$ of Brain Heart Infusion Broth (BHIB) at $30^{\circ} \mathrm{C}$ for 24 hours. The harvested bacteria were washed 3 times in $1.5 \%$ physiological saline by centrifugation at $1,000 \mathrm{~g}$ for $10 \mathrm{~min}$. The concentration of bacterial suspension was determined by spectrophotometer and diluted to $10^{9} \mathrm{cell} / \mathrm{ml}$ in $1.5 \%$ sterile physiological saline for preparation.

\section{Shrimp immunization and bacterial challenge}

A total two hundred and fourty tiger srimps were divided into four groups, each group comprised 60 tiger shrimps were immunized by OMP $10,20,30 \mu \mathrm{g} / \mathrm{kg}$ bw, and control (without immunized). The Immunizations were done by injecting OMP directly in the first swimming leg of the abdomen using a $1 \mathrm{~mL}$ syringe equipped with a 22 gauge needle. Second injection or boostering was done after 7 days first immunization. After 14 days immunization, the srimps were chalanged with $V$. harveyi for 24 hours. Sixty tiger shrimps for each treatment were cultured at 10 liters of water diluted with V. harveyi $10^{7} \mathrm{cell} / \mathrm{ml}$ in culture media for 24 hours. Another 60 tiger shrimps without immunized with OMP were cultured in standard media as control. The mortality was monitored for 1 day after infection (Jin et al. 2008). Haemolymph was collected after 24 hours infection, from abdomen sides in the second legs of shrimp by using a $1 \mathrm{ml}$ syringe equipped with a 22 gauge needle. The Haemolymph was stored at room temperature and ready to be used for sample of each parameters assay (Johansson et al. 2000).

\section{Total haemocyte count (THC)}

The THC was measured according to modified method from (Wootton et al. 2003). A hundred $\mu \mathrm{l}$ of haemolymph was transferred into a tube which contained $900 \mu \mathrm{l}$ of Natt-Herricks's stain solution. A drop of haemolymph collected from each individual was introduced into an improved Neubauer hemocytometer and the number of haemocytes was determined microscopically. THC was calculated using the following formulation (Wootton et al. 2003):

$\mathrm{THC}=\frac{\text { Total hemolymph counted } \times \text { dilution factor } \times 2 \times 10^{4}}{\text { Number of square counted }}$

\section{Differential haemocyte counts (DHCs)}

The DHCs was performed according to (Wootton et al. 2003). The haemolymph of shrimp was collected $(100 \mu \mathrm{l})$ and diluted with $100 \mu \mathrm{l}$ of TBS buffer, then a total volume of $0.2 \mathrm{ml}(200 \mu \mathrm{l})$. The cells solution was mixed well and $200 \mu \mathrm{l}$ was spread on a glass slide and placed at room temperature for 60 minutes. Then, the cells were fixed using Baker's formol calcium $(+2 \%$ $\mathrm{NaCl})$. After 30 minutes, the glass slide was rinsed with absolute methanol for 5 minutes. The cells were stained with $\mathrm{H} \& \mathrm{E}$ staining cells ( $\mathrm{pH}$ 6.6) for 5 minutes. Afterward, the slide was washed with $\mathrm{dH}_{2} \mathrm{O}$. The cell was observed under light microscope using 100x objective lenses. A minimum of 100 haemocytes per slide were examined to determine the DHC.

\section{The amount of protein plasma assay}

The in vitro amount of TPP of the haemocytes of $P$. monodon was assessed by following the modified procedure of (Van de Braak, 2002). A hundred microliters of haemolymph were centrifuged at $1500 \mathrm{rpm}$, at $4^{\circ} \mathrm{C}$, for 10 minutes. Then $0.05 \mathrm{ml}$ supernatant was mixed by adding of $1 \mathrm{mg} / \mathrm{ml}$ Bovine Serum Albumin (BSA), 
aquades $4.75 \mathrm{ml}, 0.5 \mathrm{ml} \mathrm{Alk.CuSO}{ }_{4}$ and $0.05 \mathrm{ml}$ Lowry Reagent medias, and by following the modification procedure of (Lowry et al. 1951). The values were expressed as O.D. at $660 \mathrm{~nm} / 15 \mathrm{~min}$.

\section{Superoxide dismutase (SOD) activity assay}

Superoxide Dismutase activity Assay, considered as its ability to inhibit superoxide radical, was done by previously method (Chandra et al. 2006). One unit of SOD activity was defined as the amount required to inhibit the rate of xanthine reduction by 50\% (Jin et al. 2008). Specific activity was expressed as SOD unit/mg protein.

\section{Protease enzyme activity assay}

Protease enzyme activity assay was assessed by tyrosine reduction following the modification procedure of (Celis-Guerrero et al. 2004). One unit protease activity was counted by converting the value of absorbance to tyrosine concentration (Celis-Guerrero et al. 2004).

\section{Statistical analysis}

All the immune parameters analysis was performed with the SPSS 15 statistical software. One-way analysis of variance (One-way ANOVA) was applied to analyze the differences among treatments and control. Then, a post hoc test (Duncan) was conducted to display the mean for groups in the homogenous subset.

\section{Results and discussion}

The Tiger shrimp was administered by OMP intramuscularly (IM) at $10,20,30 \mu \mathrm{g} / \mathrm{kg}$ bw. The THC was collected every two days from day 2 until day 14 after imunization. The data showed that after day 2 administered with OMP decreased THCs compared to control (day 0 ) and increased again at day 4 and day 6.
Futhermore THCs decreased again in day 8 , after second imunization, and then increased at day 10 , day 12 and day 14. This result indicated that administration OMP $20 \mu \mathrm{g} / \mathrm{kg}$ bw stimulated the highest THC in tiger shrimps compare to other doses (Figure 1). This phenomenone was similar to Johansson statement, stated that $\beta$-glucan treatment as immunostimulant could decrease haemocyte at the moment and then increased dramatically (Johansson et al. 2000). (Yeh et al. 2005) reported that administration of Sargassum duplicatum extract could increase haemocyte of Litopenaeus vannamei. Haemocyte is part of cells in haemolymph, it has function to protect infectious disease as an immune response of the invertebrate organism (Van de Braak, 2002).

\section{Total haemocyte count}

The total haemocyte count (THC) of tiger shrimp was significantly different with intramuscular administration of OMP and $V$. harveyi infections $(\mathrm{P}<0.01)$. Greatly improved THC was observed in the treatment of OMP $20 \mu \mathrm{g}$ with THC value of $317.5 \times 10^{4}$ cells $/ \mathrm{ml}$ (Figure 2).

The haemocyte circulation system may cause modulation of THC. Indeed, invertebrates (including shrimp) blood circulation system is open while haemocytes are distributed in both the vascular system and tissues. Consequently, an increase of THC values was assumed from either proliferation or movement of cells from tissues into haemolymphs. The concentration of cells varied as function of the development stage of an intermoult cycle of $P$. japonicus post larvae (Tsing et al. 1989). A decrease of THC may be due to cell lysis or increased movement of cells from haemolymph to tissues (Pipe and Cole, 1995). The decreasing of THC is also presumably due to the altered physiological conditions of the shrimp, as

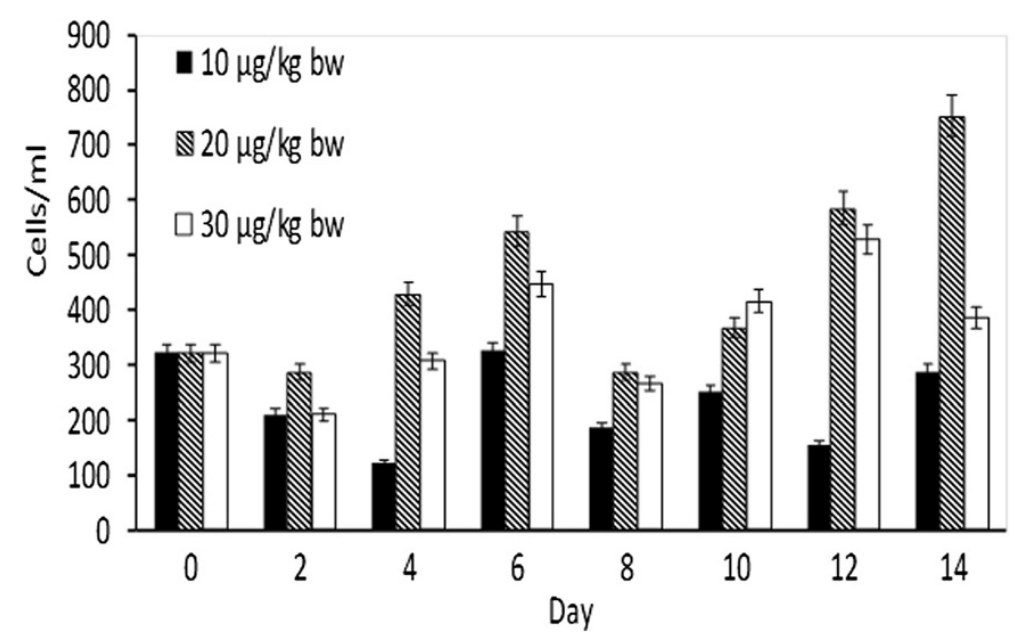

Figure 1 Effects of different dosages of intramuscular administration of OMP on total haemocyte count (THC) of tiger shrimp $\left(\times 10^{4} \mathrm{sel} / \mathrm{mm}^{3}\right)$ for fourteen days. Data are represented as mean \pm S.D. $(n=10)$. 


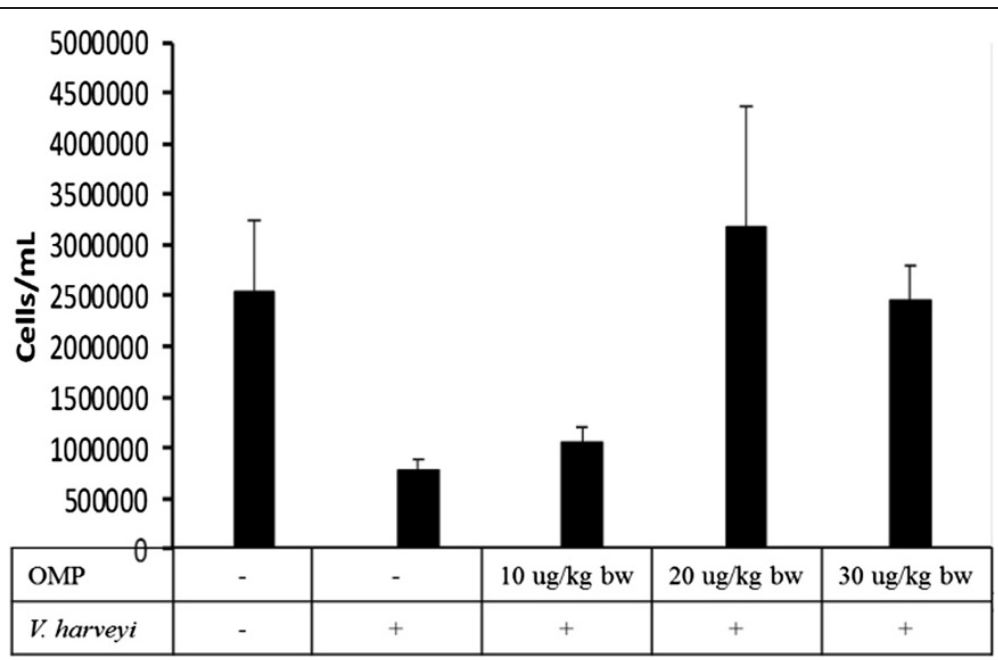

Figure 2 Effects of different dosages of intramuscular administration of OMP and $V$. harveyi infections on total haemocyte count (THC). Data are represented as mean \pm S.D. $(n=10)$. It indicates significant differences $(P<0.05)$ among five treatments determined by one-way ANOVA.

enhanced susceptibility to bacterial infection (Ford et al. 1993).

\section{Differential haemocyte count}

The DHC (hyaline, semigranular, granular) of tiger shrimp were given intramuscular administration of OMP and $V$. harveyi infections, where hyaline, semigranular, and granular were significantly different among five treatments determined by one-way ANOVA (Figure 3). Phagocytosis is believed to be one of the major cellular defence mechanisms in crustaceans. The semigranular haemocytes are the primary cells involved in the phagocytosis of foreign particles in shrimp (Bachère et al. 1995). The similar morphological haemocytes were also reported as haemoblasts in Tapes philippinarum (Matozzo et al. 2008) and
Saccostrea glomerata (Aladaileh et al. 2007b). This cells were identified with different functions which do not play a role in defensive responses like phagocytosis or encapsulation, and they lack the common intracellular enzyme systems associated with host defense, unlike hyaline and granular (Aladaileh et al. 2007b).

Granular haemocytes are also capable of phagocytosis of foreign material but with less frequency than the smaller ones (Hose and Martin, 1989). Granular cells have been proven to play a significant role in the shrimp defence system because of their antibacterial activity (Chisholm and Smith, 1995). Granular played a role in phagocytosis, which may be correlated by their capacity for intracellular killing. Moreover, several studies showed that granular contain high levels of acid phosphatase

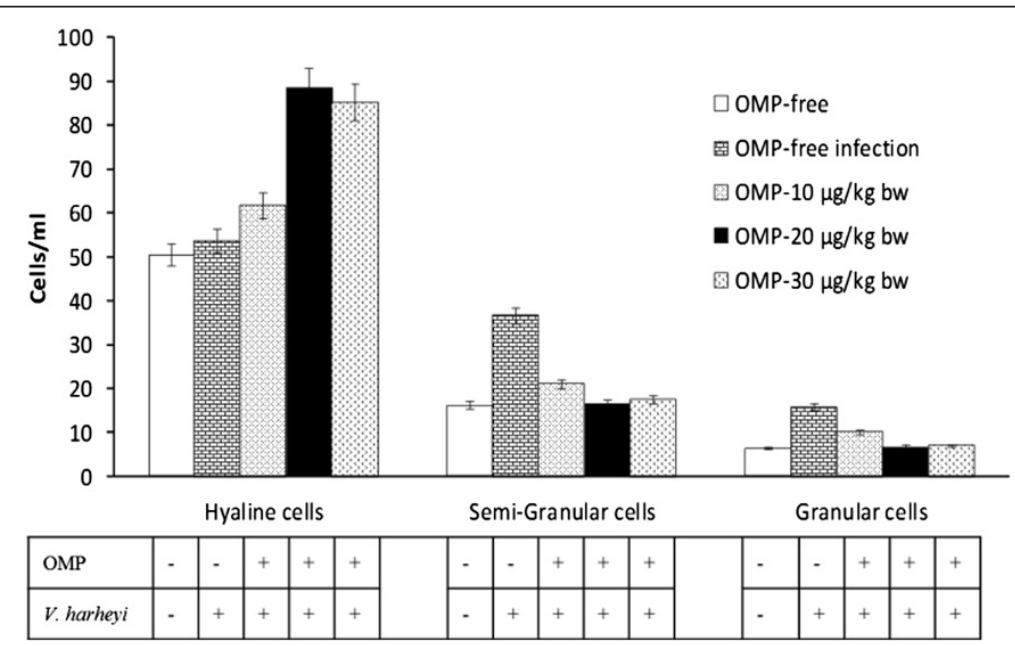

Figure 3 Effects of different dosages of intramuscular administration of OMP and $V$. harveyi infections on differential haemocyte count (DHC). Data are represented as mean \pm S.D. $(n=10)$. It indicates significant differences $(P<0.05)$ among five treatments determined by one-way ANOVA. 
and phenol oxidase enzymatic activities, as well as the ability to form superoxides and peroxides (Xue et al. 2000). The other haemocytes are the hyaline cells. They are also considered as phagocytes and superoxide anions production (Söderhäll and Cerenius, 1992).

The results of the study showed that treatment significantly increased the percentages of hyaline and decreased the percentages of semigranular and granular cells in the haemolymph. It was presumed that the young are generally known as the hyaline cells and that those cells gave rise to two haemocytic developmental series, i.e. the large- and small-granular cell line. Granular cells of the large-granular cell line mature and accumulate in the connective tissue, and many cells of the small-granular cell line were located in the lymphoid organ (Van de braak, 2002). Decreases in the percentages of semigranular and granular cells were compensated for by a proportional increase in the percentages of hyaline population. In the present study, haemocytes may display recruitment of immature cells from haematopoietic tissues (Hine, 1999). (Aladaileh et al. 2007a) predicted that the increased percentages of particular haemocyte types were due to induced cellular proliferation, recruitment of cells from non-circulating compartments of the haemolymph, or rapid cellular differentiation in response to antigenic challenge.

\section{Total plasma protein}

The total plasma protein (TPP) or haemolymph protein activity of black tiger shrimp was significantly different with intramuscular administration of OMP and $V$. harveyi infections $(\mathrm{P}<0.01)$ (Figure 4). A Great improved TPP was observed in treatment of OMP $20 \mu \mathrm{g}$ with TPP value of $16.56 \mathrm{mg} / \mathrm{ml}$ (Figure 4).
The TPP has been observed in previous studies on shrimp. The changing of TPP composition in the blood was affected with animal size, sex, nutritional state, environmental factors (such as temperature, salinity) and the moult cycle but this was inversely related to haemolymph volume (Chen and Cheng, 1993) and a decrease of TPP during infection as well as during repeated haemolymph sampling (Ford et al. 1993). In this study, TPP increased with treatment of OMP-10 and $20 \mu \mathrm{g} / \mathrm{kg}$ bw but decreased during infection of bacteria and treatment OMP-30 $\mu \mathrm{g} / \mathrm{kg}$ bw. Those were similar to (Chen et al. 1994), the TPP increased with treatment of 10 and $20 \mathrm{ppt}$ and decreased with treatment of $30 \mathrm{ppt}$.

\section{Superoxide dismutase and protease enzyme activity}

The humoral parameters are SOD and protease activities of tiger shrimp. The SOD and protease activities were significantly different with intramuscular administration of $\mathrm{OMP}$ and $V$. harveyi infections $(\mathrm{P}<0.05)$ (Figure 5). Greatly improved SOD activity was observed in the treatment of OMP $10 \mu \mathrm{g}$ with SOD value of 139,09 unit /mg protein and protease activity of OMP $20 \mu \mathrm{g}$ with protease activity value of 130,17 unit/mg protein (Figure 5).

Concern to haemocytes function, superoxide anion produces toxic oxygen metabolites. Production of toxic oxygen metabolites, such as protease and reactive oxygen species (ROS) activation anion superoxide $/ \mathrm{O}_{2}^{-}$, hydrogen peroxide/ $\mathrm{H}_{2} \mathrm{O}_{2}$, ion hydroxide/ $\mathrm{OH}^{-}$and oxygen $/ \mathrm{O}_{2}$ (Campa-Cordova et al. 2002) is believed to be mediated through phagocytosis, encapsulation, aggregate nodulation, melanocytes and cytotoxicity which destroy invasive pathogens (Rodriguez and Moullac, 2000), thus providing an explanation for the combined suppression of phagocytosis and superoxide anion (Anderson et al. 1992).

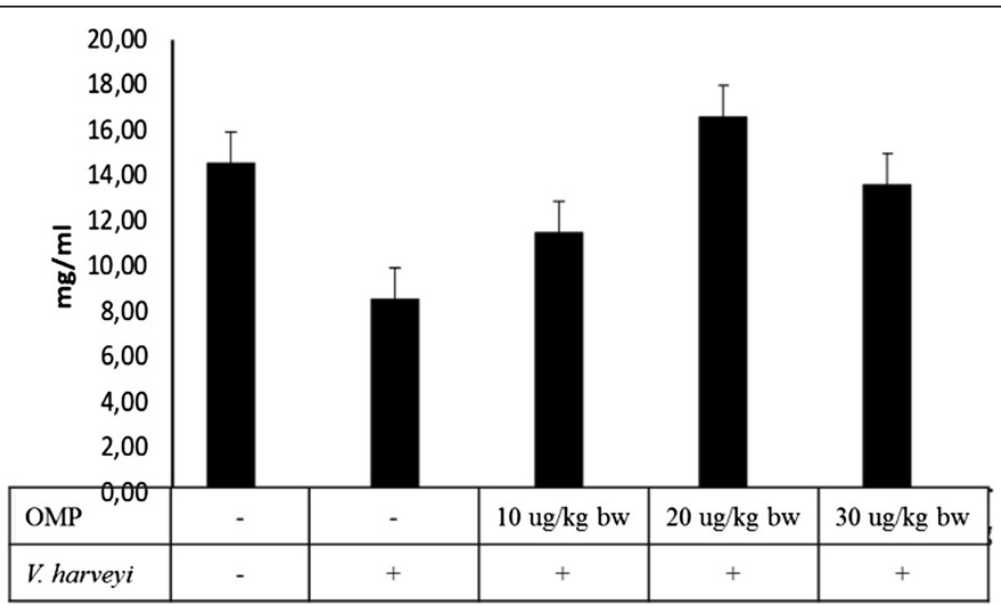

Figure 4 The Effects of different dosages of intramuscular administration of OMP and $V$. harveyi infections on total plasma protein (TPP). Data are represented as mean \pm S.D. $(n=10)$. Different letters indicate significant differences $(P<0.05)$ among five treatments determined by one-way ANOVA. 


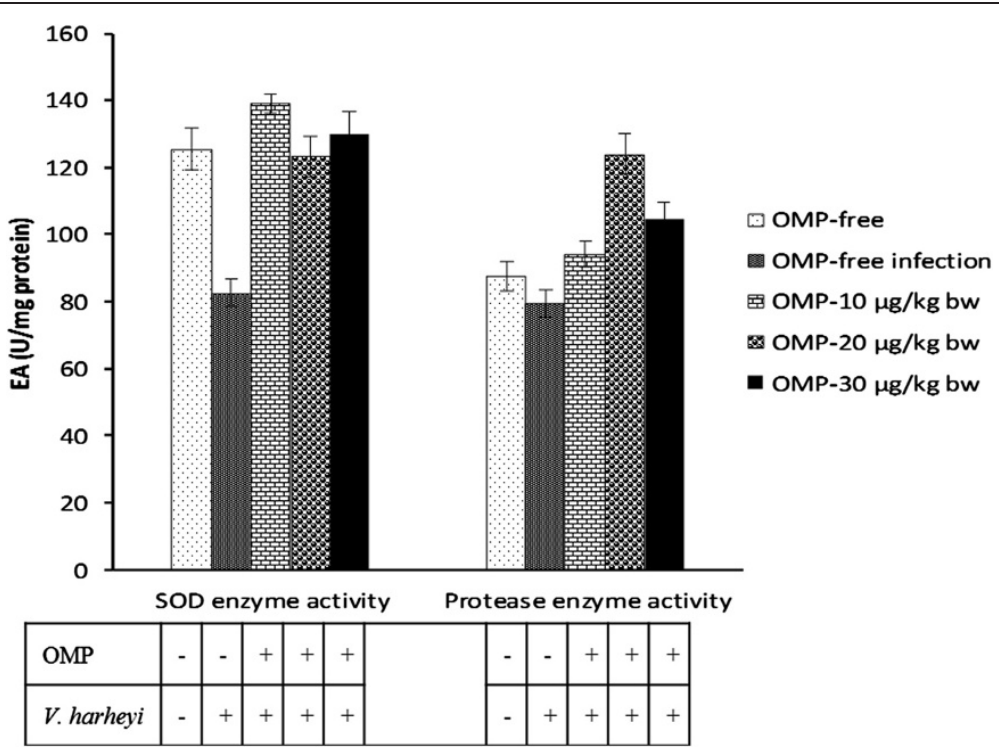

Figure 5 Effects of different dosages of intramuscular administration of OMP and $\boldsymbol{V}$. harveyi infections on superoxide dismutase (SOD) and protease activity. Data are represented as mean \pm S.D. $(n=10)$. Different letters indicate significant differences $(P<0.05)$ among five treatments determined by one-way ANOVA. EA denote enzyme activity (U/mg protein).

The levels of protease activity were enhanced, caused by intramuscular administration of OMP and $V$. harveyi infections in tiger shrimp. The protease enzyme has a role to play as a lysosomal enzyme and prophenoloxidase (proPO) activator to become a phenol oxidase (PO) enzyme (Van de Braak, 2002). During that process, it was followed by phenol oxidation to become quinone that is antibacterial molecules (Smith et al. 2003). (Yeh et al. 2005) said that immunostimulants could enhance Phenol oxidase enzyme activity. Similar study in Biomphalaria glabrata reported that serine protease enzyme activity enhancement was followed by phenol oxidase enzyme activity enhancement (Bahgat et al. 2002).

On the other hand, an alteration in the levels of superoxide anion caused by contaminant exposure has been well studied in invertebrates (Wootton et al. 2003). A study on bivalves reported that bivalves' superoxide generation is generally enhanced with low concentrations of contaminant exposure, but inhibited at higher concentrations (Dyrynda et al. 2000). In the present study, intramuscular administration of OMP and $V$. harveyi infections presented significant differences from control to produce protease and superoxide anion.

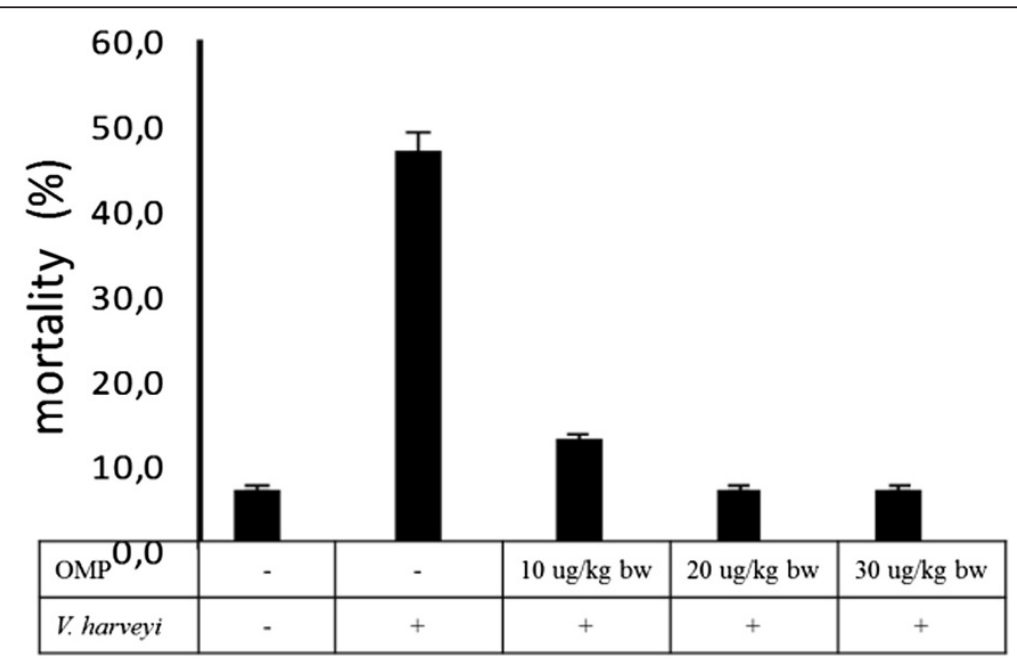

Figure 6 Cumulative mortality (\%) of tiger shrimp after two times of boosters of OMP for 14 days against $V$. harveyi infection for 24 hours. 


\section{Mortality}

Initial mortality tiger shrimp occurred on the next day after challenge. The highest cumulative mortality (46\%) was observed in tiger shrimp with the control infection (OMP-free infection) (Figure 6). While shrimp with various OMP injection had reduced mortality until of 6-13\%. Similar results had been reported in previous studies on shrimp when using immunostimulant (beta glucan) (Huang et al. 2006). In this study, treatment of OMP-20 $\mu \mathrm{g} / \mathrm{kg}$ bw by intramuscular injection showed the most efficient and desirable influence on resistance of tiger shrimp to $V$. harveyi. However, treatments of OMP-10 $\mu \mathrm{g} / \mathrm{kg}$ bw and OMP-30 $\mu \mathrm{g} / \mathrm{kg}$ bw reduced of mortality of tiger shrimp but they were not more efficient than treatment of OMP-20 $\mu \mathrm{g} / \mathrm{kg}$ bw. It probably concluded that the beneficial effect of OMP of disease resistance of tiger shrimp is dose-dependent and OMP$20 \mu \mathrm{g} / \mathrm{kg}$ bw is an optimal dose after two times of boosters of OMP for 14 days against $V$. harveyi infection for 24 hours.

\section{Conclusion}

The research demonstrated that OMP $V$. Alginolyticus administrated intramuscularly enhance immune responses as well as the resistance to $V$. harveyi in tiger shrimp. In this research, the optimal immune parameters were observed in tiger shrimp induced by OMP-20 $\mu \mathrm{g} / \mathrm{kg}$ bw.

\section{Competing interests}

The authors declare that they have no competing interests.

\section{Authors' contributions}

Maf, EP, MR, FF, RN, ES, and AS participated study design and performed the data analysis in the Experiments. HN, Mar, and Mu participated in drafting the manuscript. All authors have read and approved the final manuscript.

\section{Acknowledgements}

The research was supported by a grant from National Education Ministry of Indonesia. We thanks to Dr. Sumarno, Dr. Widodo, Dr. Supanjani, Larry Cotreen, Ph.D for their technical assistance in the experiment and publication.

\section{Author details}

${ }^{1}$ Fisheries and Marine Science Faculty, Brawijaya University, Malang, East Java, Indonesia. ${ }^{2}$ Fisheries Science Faculty, Palangkaraya University, Kalimantan, Indonesia.

\section{Received: 17 March 2013 Accepted: 27 August 2013}

Published: 3 September 2013

\section{References}

Aladaileh S, Nair VS, Birch D, Raftos AD (2007a) Sydney rock oyster (Saccostrea glomerata) haemocytes. Morphology and function. J Invertebr Pathol 96:48-63

Aladaileh S, Rodney P, Nair VS, Raftos AD (2007b) Characterization of phenoloxidase activity in Sydney rock oysters (Saccostrea glomerata). Comp Biochem Physiol 148(b):470-480

Anderson RS, Oliver LM, Brubacher LL (1992) Superoxide anion generation by Crassostrea virginica haemocytes as measured by nitroblue tetrazolium reduction. J Invertebr Pathol 59:303-307

Bachere E, Mialhe E, Notl D et al (1995) Knowledge and research prospects in marine mollusc and crustacean immunology. Aquaculture 132:17-32

Bahgat M, Doenhoff M, Kirschfink M, Ruppel A (2002) Serine protease and phenoloksidase activities in haemocytes of biomphalaria glabrata snails with varying susceptibility to infection with the parasite schistosoma mansoni. Parasitol Res 88:489-494

Campa-Cordova Al, Hernandez-Saavedra NY, De Philippis R, Ascencio F (2002) Generation of superoxide anion and SOD activity in haemocytes and muscle of American white shrimp (Litopenaeus vannamei) as a response to $\beta$-glucan and sulphated polysaccharide. Fish Shellfish Immunol 12:353-366

Celis-Guerrero LE, Fernando LGC, Angeles MNT (2004) Characterization of proteases in the digestive system of spiny lobster (Panulirus interruptus). Marine Biotechnol 6:262-269

Chandra KM, Basanta KD, Subhsah CM (2006) Effect of multiple injections of $\beta$-glucan on non-spesifik immune respone and disease resistance in Labeo rohita finger-lings. Fish Shellfish Immunol 20:305-319

Chen JC, Cheng SY (1993) Studies on hemocyanin and haemolymph protein levels of Penaeus japonieus based on sex, size and moulting cycle. Comp Biochem Physiol 106B:293-296

Chen JC, Chen CT, Cheng SY (1994) Nitrogen excretion and changes of hemocyanin, protein and free amino acid levels in the haemolymph of Penaeus monodon exposed to different concentrations of ambient ammonia$\mathrm{N}$ at different salinity levels. Mar Ecol Prog Ser 110:85-94

Chisholm JRS, Smith VJ (1995) Comparison of antibacterial activity in the haemocytes of different crustacean species. Comp Bioehem Physiol 110A:39-45

Dyrynda EA, Law RJ, Dyrynda PEJ, Kelly CA, Pipe RK, Ratcliffe NA (2000) Changes in immune parameters of natural mussel Mytilus edulis populations following a major oil spill ('Sea Empress', Wales, UK). Mar Ecol Prog Ser 206:155-170

Ford SE, Kanaley SA, Littlewood DTJ (1993) Cellular responses of oysters infected with haplosporidium nelsoni: changes in circulating and tissue-infiltrating haemocytes. J Invertebr Pathol 61:49-57

Garavito RM, Rosenbusch JP (1986) Isolation and crystallization of bacterial porin. Methods Enzymol 125:309-328

Hine PM (1999) The inter-relationships of bivalve haemocytes. Fish Shellfish Immunol 9:367-385

Hose JE, Martin GG (1989) Defense functions of granulocytes in the ridgeback prawn Sicyonia ingentis. J Invert Pathol 53:335-346

Huang $X$, Zhou H, Zhang H (2006) The effect of sargassum fusiforme polysaccharide extract on vibriosis resistance and immune activity of shrimp, Fenneropenaeus chinensis. Fish Shelfish Immunol 20:750-757

Jin Z, Wang YH, Chu J, Luo L-Z (2008) Improvement of innate immune responses and defense activity in mitten crab (Eriocheir sinensis) by oral administration of $ß$ glucan. Biotechnol Lett 30:1721-1725

Johansson MW, Keyser P, Sritunyalucksana K (2000) Crustacean haemocytes and haematopoiesis. Aquaculture 191:45-52

Lowry OH, Rosenbrough NJ, Farr AL, Randall RJ (1951) Protein measurement with the follin phenol reagent. J Biol Chem 193:265-275

Maftuch (2006) Outer membrane protein (Omp) Vibrio alginolyticus vaccine against vibrio disease on grouper. Disertation. Brawijaya University, Malang, p 174

Matozzo V, Monari M, Foschi J, Papi T, Cattani O, Marin GM (2008) Exposure to anoxia of the clam Chamelea gallina: I. Effects on immune responses. J Exp Mar Biol Ecol 325:163-174

Pipe RK, Coles JA (1995) Environmental contaminants influencing immune function in marine bivalve mollusks. Fish Shellfish Immunol 5:581-595

Radriguez J, Moullac GL (2000) State of the art of immunological tools and health control of penaied shrimp. Aquaculture 191:109-119

Sadovy Y (2000) Regional survey for fry and fingerling supply and current practices for grouper mariculture. Evaluating current status and long term prospects for grouper mariculture in south east Asia. Final report to the collaborative APEC grouper research and development network. (FWG 01/99)

Sakai M (1999) Current research status of fish immunostimulants. Aquaculture 172:63-92

Smith VJ, Brown JH, Hautona C (2003) Immunostimulation in crustaceans: does it really protect against infection? Fish Shellfish Immunol 15:71-90

Söderhäll K, Cerenius L (1992) Crustacean immunity. Annu Rev Fish Dis 2:3-23

Tsing A, Arcier JM, Brehélin M (1989) Haemocytes of penaeid and palaemonid shrimps;morphology, cytochemistry, and hemograms. J Invertebr Pathol 53:64-77

Van de Braak K (2002) Haemocytic defence in balck tiger shrimp (Penaeus monodon). PhD Degree. Wageningen University, Netherland, 159

Wootton EC, Dyrinda EA, Pipe RK, Ratcliffe NA (2003) Bivalve immunity: comparisons between the marine mussel (Mytilus edulis), the edible cokle (Cerastoderma edule), and the razor shell (Ensis siliqua). Fish Shellfish Immunol $15: 195-210$ 
Xue Q, Renault T, Cochennec N, Gerard A (2000) Separation of European flat oyster, Ostrea edulis, haemocytes by density gradient centrifugation and SDS-PAGE characterisation of separated haemocyte sub-populations. Fish Shellfish Immunol 10:155-165

Yeh ST, Chiu S, Lee JCC (2005) Administration of hot-water extract of brown seaweed Sargassum duplicatum via immersion and injection enhances the immune resistance of white shrimp Litopenaeus vannamei. Fish Shellfish Immunol 20:332-345

doi:10.1186/2193-1801-2-432

Cite this article as: Maftuch et al:: Improvement of innate immune

responses and defense activity in tiger shrimp (Penaeus monodon Fab.)

by intramuscular administration of the outer membrane protein Vibrio alginolyticus. SpringerPlus 2013 2:432.

\section{Submit your manuscript to a SpringerOpen ${ }^{\circ}$} journal and benefit from:

- Convenient online submission

- Rigorous peer review

- Immediate publication on acceptance

- Open access: articles freely available online

- High visibility within the field

- Retaining the copyright to your article 